\title{
A Novel Two-Dimension' Customer Knowledge Analysis Model
}

\author{
Liu Xuelian ${ }^{1,2}$, Nopasit Chakpitak $^{1} \&$ Pitipong Yodmongkol ${ }^{1}$ \\ ${ }^{1}$ College of Arts Media and Technology, Chiang Mai University, Chiangmai, Thailand \\ ${ }^{2}$ School of Tourism, Convention and Exhibition, Chengdu University, Chengdu, China \\ Correspondence: Liu Xuelian, College of Arts Media and Technology, Chiang Mai University, Huaykeaw Rd, \\ Chiangmai, Thailand. E-mail: 420631036@qq.com
}

Received: March 17, 2015 Accepted: May 13, 2015 Online Published: June 13, 2015

doi:10.5539/ass.v11n16p257 URL: http://dx.doi.org/10.5539/ass.v11n16p257

\begin{abstract}
Customer knowledge has increasingly importance in customer-oriented enterprise. Customer knowledge management process with models can help managers to identify the real value chain in business process. The purpose of the paper is to develop a tool for classification and processing of customer knowledge from perspective of knowledge management. By review previous customer knowledge management model, this paper proposes a novel two-dimension' customer knowledge analysis model, which make customer knowledge more understandable and manageable. The two-dimensions are customer's scope and variability. Base on the model, the process strategies for each kind of customer knowledge are given. To verify the effectiveness of this model, a case study was conducted in a hotel and shows the application of the CKM model in customer knowledge management process can lead to increased process performance. This sample analysis model acts as a guide in practice to help enterprise to develop proper methods in customer knowledge system.
\end{abstract}

Keywords: knowledge management, customer knowledge, customer knowledge management, knowledge co-creation, process management, analysis model, hospitality

\section{Introduction}

\subsection{Challenges for Understanding Customers}

In the age of information, the core competence of enterprises is differentiation rather than scale. To achieve differentiation, one good way for enterprises is better known of their customers. Unfortunately, customers are so elusive and unpredictable. Few firms are able to manage the dialogue with their customers effectively and use their knowledge to create more value for customers and improve firm performance significantly(Smith, 2005). Typically, they use Customer Relationship Management (CRM) system to capture, storage and discover the customer related information, such as customer name and favorites. Some companies try to employ measurement tools to identify a customer's value to the organization (Reinartz \& Kumar, 2002). With the database technology development, companies use data analysis and data mining to get the whole picture of their customers' demographic and behavioral patterns and re-partition their customers into different categories. But most of companies just only have the information and utilize surface value for improve customer loyalty and satisfaction (Zanjani, Rouzbehani, \& Dabbagh, 2008). As a result, they do not know how to use what they know to provide better products or services for their customers and develop differentiation against their competitors. One possible solution is to combine the Knowledge Management (KM) method to CRM system so it is possible to develop a Customer Knowledge Management process. The CKM process with models can help managers to find the real value chain specifically in service-oriented business. This method helps companies to improve knowledge management performance for their business processes, which aims to develop the differentiation of their products and services.

Some e-business enterprises, such as Google, e-Bay and Amazon, using customer knowledge to improve the customers' experience. These companies obtain competition advantages by process customer knowledge. Using knowledge to support customers was found to be an important factor in retaining existing customers (Desouza \& Awazu, 2004).

\subsection{Research Goals and Structure}

The research focuses on how to understand CKM concepts and applied it within the area of service-oriented 
business. The method makes companies understand CKM in a deeper level, which aims at improving their service quality and making differentiation.

To achieve the research goals, firstly the theory of knowledge management and CK \& CKM are reviewed, then the customer co-creation models are also discussed in section 2. Base on that, in section3, a two-dimension analysis model for CKM is proposed, which makes the concept of CKM more clarity and more operational. An action research case is illustrated in section 4 with the proposed analysis model. At last, section 5 gives the conclusion and the future of this research. The research framework shows in Figure 1.

There are four phases in this research, which includes pre-understanding, analysis, model development and case study. By follow these steps, an analysis model is developed and tested in a real company.

\begin{tabular}{|c|c|c|c|}
\hline $\begin{array}{l}\text { Phase } 1 \\
\text { Pre-understanding }\end{array}$ & $\begin{array}{l}\text { Phase } 2 \\
\text { Analysis }\end{array}$ & $\begin{array}{l}\text { Phase } 3 \\
\text { Model development }\end{array}$ & $\begin{array}{l}\text { Phase } 4 \\
\text { Case study }\end{array}$ \\
\hline $\begin{array}{l}\text { Literature } \\
\text { identification } \\
\text { Planning research } \\
\text { methodology } \\
\text { Expert interviews }\end{array}$ & $\begin{array}{l}\text { Literature review } \\
\text { Analysis of } \\
\text { secondary data } \\
\text { Model preliminary } \\
\text { development }\end{array}$ & $\begin{array}{l}\text { Analysis of key } \\
\text { factors } \\
\begin{array}{l}\text { Development of } \\
\text { model } \\
\text { Model refinement }\end{array}\end{array}$ & $\begin{array}{l}\text { Identification of case } \\
\text { company } \\
\text { Company interviews } \\
\text { Model testing }\end{array}$ \\
\hline
\end{tabular}

Figure 1. Research framework

\section{Literature Review}

\subsection{Knowledge Management}

The knowledge management literature provides some background theory of this research. Since massive research concern knowledge management, we only review the conception used in this research. The knowledge concept in business process was discussed in many papers. Hanvanich et al. (Hanvanich, Dröge, \& Calantone, 2003) discuss that there are three key marketing process, product development management, customer relationship management and supply chain management, contains the marketing knowledge. They also find the marketing knowledge can be measured by evaluating awareness of factors, control of factors, and application of knowledge in new market.

One of definition of knowledge is from Davenport and Pruzak's as a 'fluid mix of framed experience, values, contextual information and expert insight that provide a framework for evaluation and incorporating new experiences and information' (Davenport \& Pruzak, 2000). This research employs the definition as the base theory.

\subsection{Customer Knowledge}

Customer knowledge is a hot research topic in recent years; it is varying from different background and research purpose. CKM is composed from the management and discovery of customer knowledge. In respectively early year, Rowley proposed two types of customer knowledge (Rowley, 2002):

Knowledge about customers, this includes knowledge about customer, potential customers and individual customers.

Knowledge possessed by customers, covered wide range of knowledge about products and service from use experiences to products deliver ways.

While García (García-Murillo \& Annabi, 2002) made a distinction of customer knowledge as:

(a) The knowledge that the customer has about the issues that are related to the product or services that he is interested in buying;

(b) The knowledge that the firm should have that can be used to assist the customer in making a purchase decision.

Base on García's results, Gebert (Gebert, Geib, Kolbe, \& Brenner, 2003) argues that knowledge flows in customer relation management processes can be classified into three categories:

Knowledge for customers is the knowledge customer need for using products, markets and suppliers. 
(García-Murillo \& Annabi, 2002).

Knowledge about customers is accumulated to understand customer's motivations and to address them in a personalized way. This includes customer histories, connections, requirements, expectations, and their purchasing activity (Day, 2000).

Knowledge from customers is customers' knowledge of products, suppliers and markets. This knowledge can be collected by feedback process to support continuous improvement (García-Murillo \& Annabi, 2002).

A later research illustrated a different customer knowledge categories framework (Smith, 2005), it shows in Figure 2 .

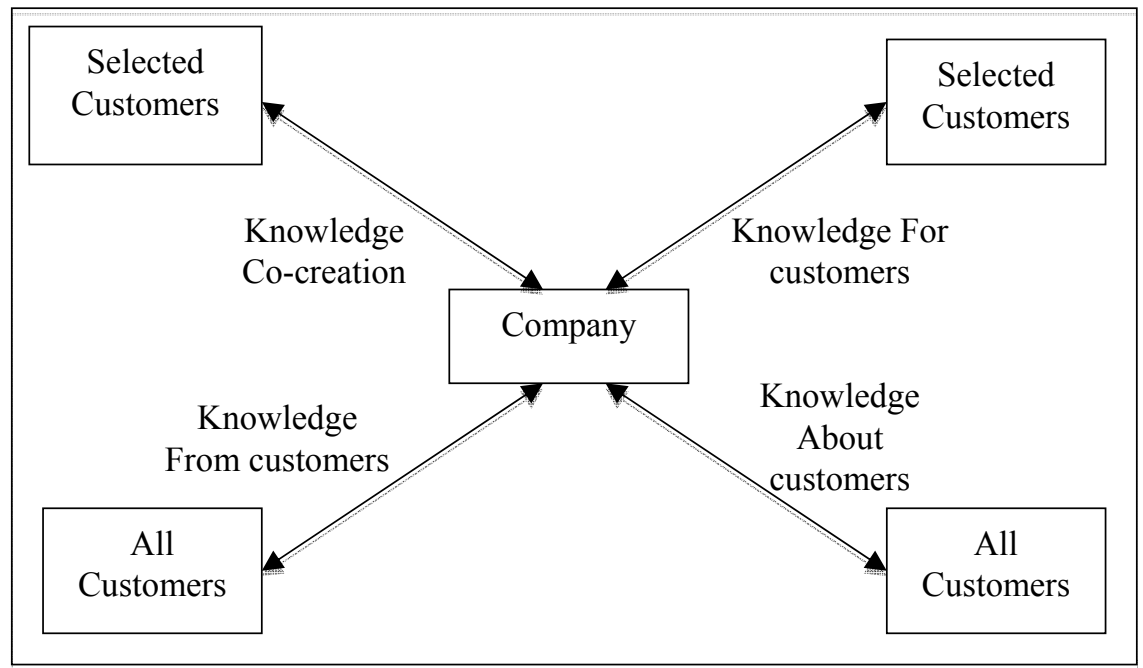

Figure 2. A concept framework for CKM (Smith, 2005)

Four categories of customer knowledge including:

\section{Knowledge about customers}

Knowledge about customers is the foundation of CKM system and it is generated from data analysis and data mining. It not only includes basic data about a customer (e.g., name, contact information), a purchasing record of products or services, but also customer group's preferences from statistic (e.g., language, method of communication). It is the knowledge of customer linking to products, suppliers and markets.

\section{Knowledge for customers}

Knowledge for customers include knowledge an organization provides to its customers (Gebert et al., 2003). This kind of customer knowledge includes all information and expertise about products and services developed by marketing or R\&D, it also includes wide range source of knowledge developed by third party even customers themselves.

\section{Knowledge from customers}

Knowledge from customers is the knowledge collected from customers directly. For customers are a strategic opportunity for companies to learn (Zack, 2003), awareness of the knowledge mastered by customer, their feel of products and services, is an increasing import part of an organization's knowledge (Rowley, 2002). Companies need proper feedback methods to accumulate this kind of knowledge. This helps companies improve their products and services continually; focus on right markets division; make proper business strategies; and develop new products and services to satisfy their customers. (Rowley, 2002). Good companies encourage customers share their experiences (good and bad) and viewpoints. Customers intend to be more loyalty when their comments been taken seriously. (Gibbert, Leibold, \& Probst, 2002). This kind of knowledge can create from wide range of sources, and be combined with business process to help managers improving their work in a range of levels from top to front-line. (Gebert et al., 2003).

\section{Knowledge co-creation}

The previous knowledge types are all transfer in a one-way pattern. In practice, there is another way of customer knowledge creation. In this way, companies and customers involved in a high interaction process. Not only companies staffs, but also customers act as knowledge development partners (Gibbert et al., 2002). They work 
together through different ways to develop products or services, as well as knowledge. For products development, there is a well-known "Crowd-sourcing" model. For the customer needs and expectation is not clear even in customer's mind, just ask customer what they need is far from the proper direction in most cases. The benefit of knowledge co-creation is discovering the real needs of customer by true collaboration. (Gibbert et al., 2002). It is a big challenge to develop a platform for getting customers to cooperate more effectively. (Davenport, Harris, \& Kohli, 2001).

From the name of CKM, it is obviously that the conception is from the CRM and KM. The concepts of CRM and knowledge management (KM) both focus on allocating resources to supportive business activities in order to gain competitive advantages (Gebert et al., 2003). CRM focuses on managing the relationship between a company and its current and potential customers through collecting massive data related the customers. KM recognizes the knowledge available to a company as a major success factor.

\subsection{Customer Knowledge Co-creation Models}

In order to develop the concept of customer knowledge co-creation, the literature of customer co-creation models are reviewed.

M. Etgar (2007) presented a model of consumer engagement in co-production. The author developed a five-stage dynamic model of consumer involvement in co-production, and discussed the basic linkages between co-production and customization and presents co-production as a dynamic process, which is composed of five distinct stages.

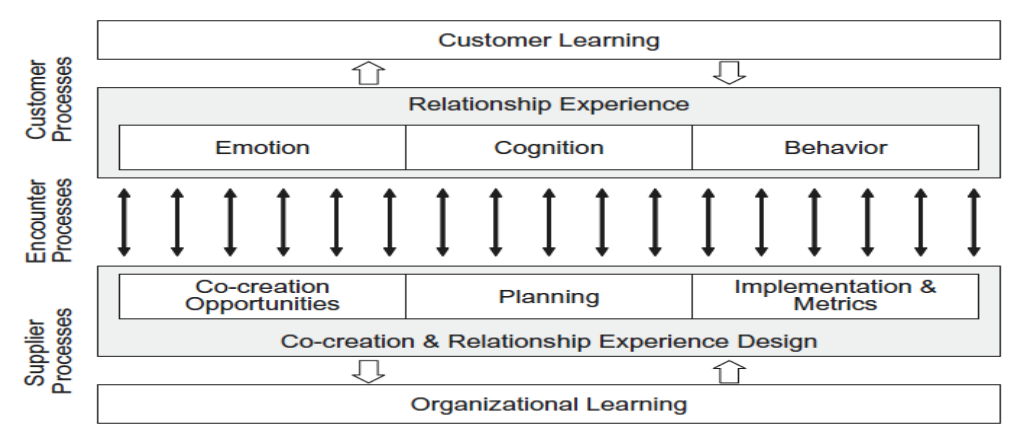

Figure 3. Model of consumer knowledge co-creation (Etgar, 2007)

Payne et al. (2007) explored the value co-creation process in the background of S-D logic. The field-based research also illustrates practical implantation of the framework. For regard customer as an important value co-creator in company, this framework discovered the key foundational propositions of S-D logic.

Payne et al. (2009) examined the concept of brand relationship experience in the context of co-creation and service-dominant logic and outline a conceptual model for designing and managing the customer experience. Case study research illustrates how this model helps in the design and management of the brand relationship experience for an innovative new product.

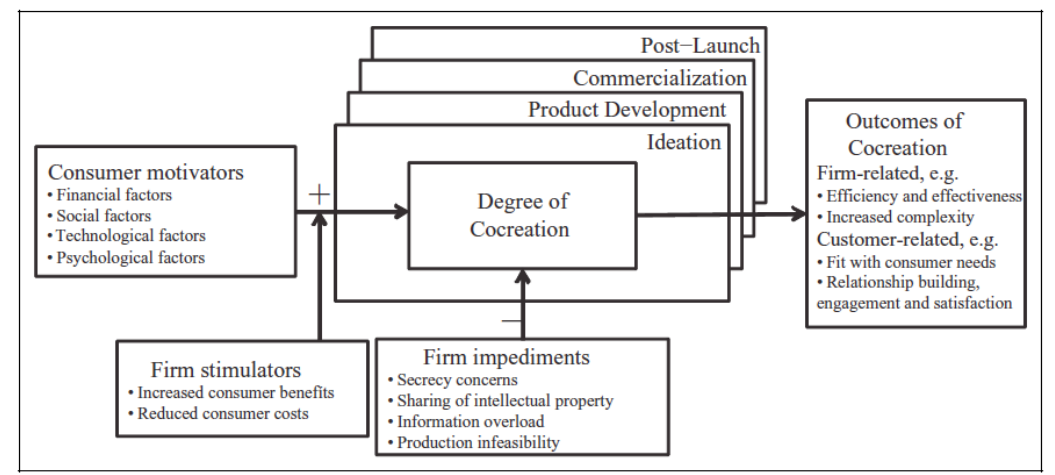

Figure 4. Conceptual framework of consumer co-creation in new product development (NPD) (Hoyer et al., 2010) 
Vargo et al. (2008) presented one perspective of an intersection, involve in technology services and service dominant (S-D) logic. They admit (1) service, the application ability (such as knowledge and skills) from one party to another, is the foundation of exchange; (2) the service system is appropriate unit of analysis for service exchange, which connecting with other systems' value propositions. It is a kind of configuration of resources (including human resources, information and Technology); and (3) the service science is the study of service system and work together to create value through complex configuration in the allocation of resources.

Hoyer et al. (2010) proposed a conceptual framework that focuses on the degree of consumer co-creation in new product development (NPD). The authors examine (a) the major stimulators and impediments to this process, (b) the impact of co-creation at each stage of the NPD process, and (c) the various firm-related and consumer-related outcomes.

Grissemann et al. (2012) developed a conceptual model of customer co-creation of tourism services and empirically tests this model in a travel agency context. Company support for customers is found to significantly affect the degree of customer co-creation. The degree of co-creation further positively affects customer satisfaction with Service Company, customer loyalty, and service expenditures.

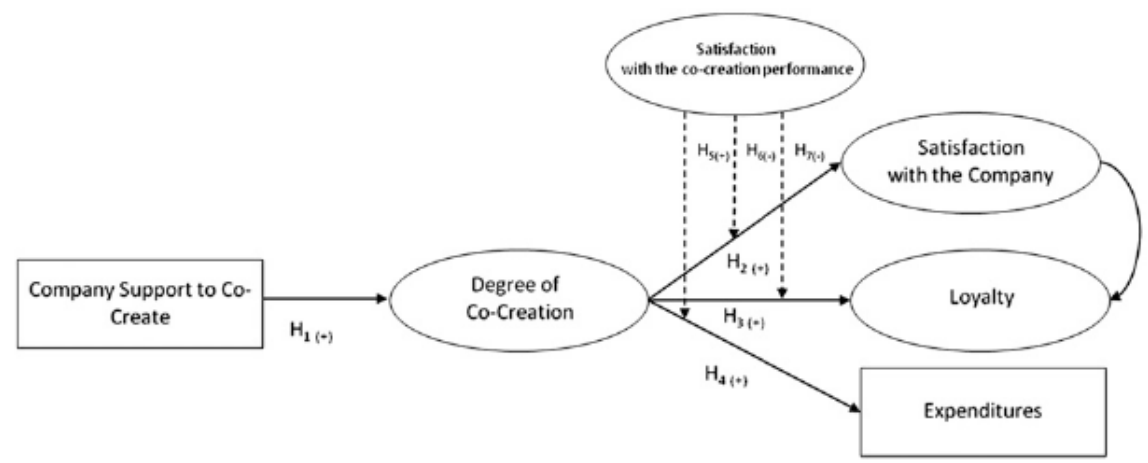

Figure 5. Conceptual model of customer co-creation of tourism services (Grissemann \& Stokburger-Sauer, 2012)

Grönroos et al. (2011) adapting a multi-dimensional service logic to analyze the value creation process in business relationship. In this process, services act as a mediating factor. The processes of value creation, purchasing, usage and marketing are inter-waved with each other. Managers can improve their services by adopting this perspective. They also analyzed the base logic of industrial interactions.

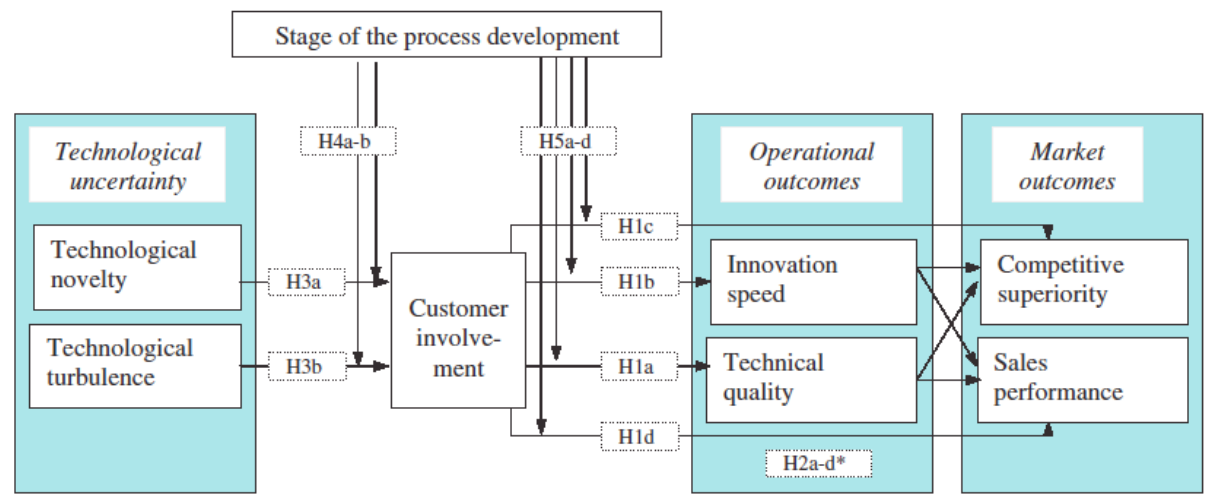

* Indirect effect of customer involvement on market outcomes via operational outcomes

Figure 6. Customer involvement model in new service development (Carbonell et al., 2009)

Bowden (2009) proposed a conceptual framework for distinguish customer-brand relationships sectors based on the extent to new or repeat customers of one brand.

Customer responses to service are more difficult to capture in current circumstance, so it cannot be measured by 
customer satisfaction survey. The framework helps company's better understanding of customer-brand relationships and the processes.

Carbonell et al. (2009) confirm the role of technological as an antecedent to customer involvement. Their study also proposes and tests a nomological network of relationships between customer involvement and several measures of new service performance. In terms of managerial implications, their study offers critical insights on how customer involvement in new service development translates into improved new service performance.

Lusch et al. (2007) developed nine derivative propositions that inform marketers on how to compete through service.

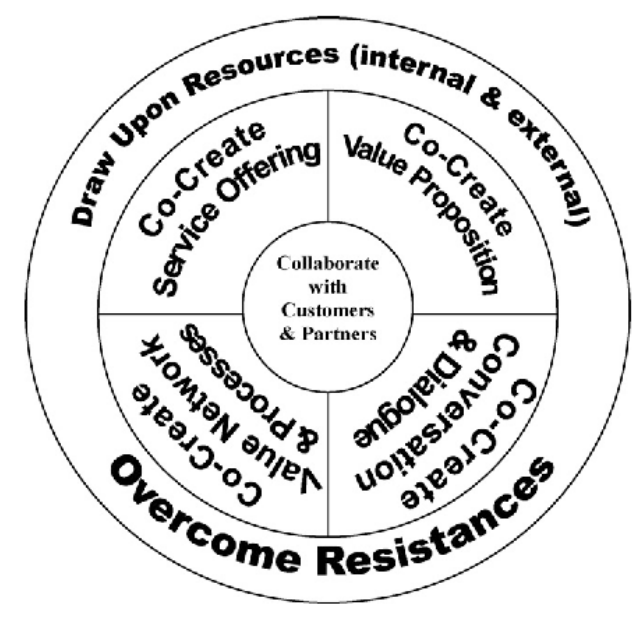

Figure 7. Service-dominant marketing (Lusch et al., 2007)

Table 1. Summary of customer co-creation models

\begin{tabular}{|c|c|c|c|}
\hline Author(s) & Year & Summery & Category \\
\hline M. Etgar & 2007 & $\begin{array}{l}\text { A five-stage dynamic model of consumer involvement } \\
\text { in co-production }\end{array}$ & $\begin{array}{l}\text { Description } \\
\text { model }\end{array}$ \\
\hline $\begin{array}{l}\text { A. F. Payne, Storbacka, \& } \\
\text { Frow }\end{array}$ & 2007 & $\begin{array}{l}\text { A conceptual framework for understanding and } \\
\text { managing value co-creation }\end{array}$ & $\begin{array}{l}\text { Conceptual } \\
\text { model base on } \\
\text { process }\end{array}$ \\
\hline $\begin{array}{l}\text { A. Payne, Storbacka, \& } \\
\text { Frow }\end{array}$ & 2009 & $\begin{array}{l}\text { A conceptual model for designing and managing the } \\
\text { customer experience }\end{array}$ & $\begin{array}{l}\text { Conceptual } \\
\text { model base on } \\
\text { process }\end{array}$ \\
\hline Vargo, Maglio, \& Akaka & 2008 & $\begin{array}{l}\text { One perspective which representing the intersection of } \\
\text { two growing streams of thought, service science and } \\
\text { service-dominant (S-D) logic }\end{array}$ & $\begin{array}{l}\text { Conceptual } \\
\text { model }\end{array}$ \\
\hline $\begin{array}{l}\text { Hoyer, Chandy, Dorotic, } \\
\text { Krafft, \& Singh }\end{array}$ & 2010 & $\begin{array}{l}\text { A conceptual framework that focuses on the degree of } \\
\text { consumer co-creation in new product development }\end{array}$ & $\begin{array}{l}\text { Conceptual } \\
\text { model }\end{array}$ \\
\hline $\begin{array}{l}\text { Grissemann } \\
\text { Stokburger-Sauer }\end{array}$ & 2012 & $\begin{array}{l}\text { A conceptual model of customer co-creation of tourism } \\
\text { services and empirically tests this model in a travel } \\
\text { agency context }\end{array}$ & $\begin{array}{l}\text { Conceptual } \\
\text { model }\end{array}$ \\
\hline Bowden & 2009 & $\begin{array}{l}\text { A conceptual framework for segmenting customer-brand } \\
\text { relationships based on the extent to which customers are } \\
\text { either new or repeat purchase customers of a specific } \\
\text { service brand }\end{array}$ & $\begin{array}{l}\text { Conceptual } \\
\text { model }\end{array}$ \\
\hline $\begin{array}{l}\text { Carbonell, } \\
\text { Rodríguez-Escudero, \& } \\
\text { Pujari }\end{array}$ & 2009 & $\begin{array}{l}\text { A theoretical framework for impact of customer } \\
\text { involvement on operational and market dimensions of } \\
\text { new service performance }\end{array}$ & $\begin{array}{l}\text { Theoretical } \\
\text { model }\end{array}$ \\
\hline Lusch, Vargo, \& O’Brien & 2007 & $\begin{array}{l}\text { A model with nine derivative propositions that inform } \\
\text { marketers on how to compete through service }\end{array}$ & $\begin{array}{l}\text { Conceptual } \\
\text { model }\end{array}$ \\
\hline
\end{tabular}


Shaw et al. (2011) introduced the concept of service-dominant logic as a research paradigm in marketing management and demonstrates the importance of service-dominant logic in uncovering the role played by co-production and co-creation in the tourism industry. These ideas are developed in detail through a case study of the UK hotel industry that draws on new empirical research undertaken by the authors.

Kracht \& Wang (2010) proposed a complex network which indicates that the advance of information and communication technology has not reduced the number of intermediaries in the distribution channel, but rather resulted in an increasingly complex array of intermediaries.

Table 1 shows the summary of these models.

\section{A Two-Dimension Analysis Model for CKM}

From the customer knowledge literature reviewed above, the previous researches mainly focus on the conceptual framework and process framework. As with other aspects of $\mathrm{KM}$, the most significant challenges in implementing CKM effectively are organizational, not technical (Smith, 2005). The main obstacle of most applications of CKM is absence of a simple and easy understanding model to analyse customer knowledge in practice.

A novel analysis model for CKM is proposed to address this problem, which can improve CKM process design both in conception and practice aspects. The model illustrated in figure 3. For keeping same preposition form we use knowledge with customers instead of knowledge co-creation in former's models. So, the customer knowledge is assorted as: knowledge about customer, knowledge from customer, knowledge for customer and knowledge with customer.

In this model, two dimensions are employed to construct the matrix. The first dimension is the customers' scope: from all customers to selected customers. This dimension identifies the different range of customers involve in different type of customer knowledge. With known of that, the managers and front-line workers can use different strategy to collect, distribute or create customer knowledge.

The second dimension is the variability of knowledge, from static to dynamic. From the knowledge definition of Davenport and Pruzak (Davenport \& Pruzak, 2000), the knowledge is a kind of mixed fluid. One characteristic of fluid is the variability, so the knowledge can be static or dynamic respectively. With known of that, the managers and CKM system designer can use different methods to process customer knowledge.

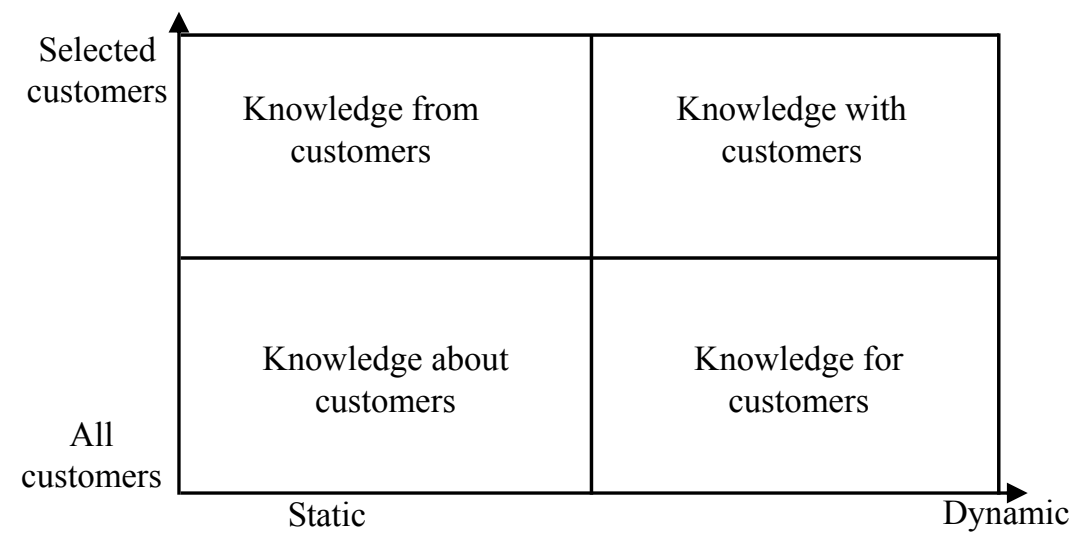

Figure 8. Two-dimension CKM analysis model

The knowledge about customers is the base of all other types of knowledge, which locate in the lower left of the matrix. This type of customer knowledge is based on the data and information about customer, not only from inside of company, but third part even whole society. "They may know more about their customers but they don't know the customers themselves or how to attract new ones" (Davenport et al., 2001). Companies need framed experience, values, contextual information and expert insight rather than just data and information. To be used, this knowledge must also be integrated across processes, information and technology. The model tell that this kind of customer knowledge is covering all customer and respectively static. The strategy to process this kind of CK is widely collected and storage. Furthermore, this kind of customer knowledge should be the identify information in customer knowledge management system. Then it needs statistics methods to get the whole picture of customers and their characteristics. 
The knowledge for customers is the knowledge that helps customers to obtain maximum product or service value. It not only comes from company itself, but also from other customers and the third party. The position of it in matrix is lower right. That means this kind of knowledge is for all customers, and it is dynamic. It includes product manual, user experience, best practice, sometime even including the culture and history of product or brand, which become the highly attractive part of consumption experience. This kind of knowledge needs to deliver to all customers and it requires managers to improve this part continually.

The knowledge from customers is a traditional and direct source of customer knowledge for companies. Typically, it comes from interview, questionnaires and investigations in customers. The main source of this kind of customer knowledge is customer feedback even complain. This kind of knowledge helps company improve their products or services. It is locate in higher left of the matrix, which means it is for selected customers and respectively static. It can be understand that the valuable knowledge only comes from part of customers. The static property presents this kind of customer knowledge is stable.

The knowledge with customers is also named knowledge co-creation. This is the newest and most complex knowledge in these four, and it shapes the future of business. The new business trend relates this kind of knowledge including prosumerism, mutual innovation and communities of creation. The examples can be found in Google, Facebook and IKEA. From exist customer co-creation models review in section 2.3; the knowledge is only for selected customers and dynamic. So it is at higher right position in the matrix. This kind of knowledge is most valuable but difficult to obtain. Since company employees and their customers create it with high degree of cooperation. The investigation to knowledge with customer related platform should be considered and enhance.

The strategy for manage customer knowledge depends on the different business type. For the common process, firms firstly need to build up CKM with about customer knowledge. That is the stage one. From the model proposed in this paper, this kind of customer knowledge is for all customer and static. That constructs the basement of CKM. In stage two, there are two things need to do, the first thing is collecting knowledge from customers, and the second thing is disseminating knowledge for customers. The stage three will focus on the knowledge co-creation with customers. In this stage, a knowledge co-creation platform needs to be built.

\section{Case Study of CKM in hospitality}

The following Case study research of a five star luxury hotel shows the importance of deep understanding the knowledge characteristics in CKM practice. The investigation focuses on an important apartment within modern service management, Customer Relationship Department (CRD), which responsible for serves government and business guests and some common customers. This department have 10 staffs who support customers depending on expertise and knowledge to resolve inquiries about a wide array of issues connected to hotel service and related business or tourism issues. They also collect customers' feedback and information from specific website, face-to-face talking and frontline workers.

\subsection{Challenges}

With the purpose of satisfying the needs of their customers and improve hotel service quality, CRD staffs utilize different information channels collecting customers' knowledge and distribute to customers or other department. On one side, the content was broadcast via internal TV channel, booklet and themed events. The selected knowledge passes to other departments through "Information liaison letter". Each CRD agent had to organize the content individually base on their own experience and new employees had to do the same things. As the amount of content increased, the CRD agents tended to use their computer documents folder for knowledge storage. For customer knowledge processed in same method and same strategy without classification, the CRD staffs have to deal with knowledge regard to their experience. It creates more chaos after knowledge transferred to other departments. The existing solution lead to difficult for knowledge creating, transferring and sharing. This process with only very basic support by internal hotel information management systems.

\subsection{Relevant Knowledge Aspects}

The purpose of the project was to provide the CRD employees with knowledge understanding and classification, thereby focus on customer knowledge flow can be divided and processed by different strategy. This also applied to information management system since the CRD staffs had no adequate method to help them structure the knowledge and organizing existing documents. Until the project start, CRD agents had to reform content with office software. To resolve the problem, the customer knowledge management model is employed to make knowledge structured and accessible, also make the whole process clearly. The model for the CRD staffs enables them to collect new knowledge with purpose and provides an whole picture of existing knowledge. They can be process and edited with proper methods. The knowledge about customer, collected by online booking system and 
reception, storage as static data, then produce statistic results about customers, for example, customer geographical distribution and age distribution. The knowledge for customers, as a dynamic content and for all of customers, updates regularly with CRD and distribute to other departments. CRD agents collect knowledge from customers by online feedback system and face-to-face communication.

\subsection{Results}

By employ the customer knowledge analysis model, CRD agents improve knowledge management performance significantly. This research interviewed all the 23 CRD agents in this hotel. CRD agents are supported by the new structure and knowledge process strategies which also available on the knowledge platform. The knowledge is better organized and transferred more efficiently. The information support team found that the cost and time needed to maintain the new platform were greatly reduced. The knowledge management structure could be maintained much more easily. Agents can find and publish the useful knowledge easier and cheaper by employing the analysis model.

\section{Conclusion}

The understanding of customers can lead to differentiation for a company, which is the core competition ability. CKM process helps company communication with their customers. On the one side, the understanding for the customer knowledge is an important step for the whole CKM process. This paper proposes a CKM analysis model to reveal the properties of customer knowledge. The case study shows the application of the CKM model can lead to increased process performance. The future research will focus on the knowledge with customers, which create strong connection between customers and company. That already and will continue create more compatible business models.

\section{References}

Bowden, J. L. H. (2009). The Process of Customer Engagement: A Conceptual Framework. The Journal of Marketing Theory and Practice, 17(1), 63-74. http://dx.doi.org/10.2753/MTP1069-6679170105

Carbonell, P., Rodríguez-Escudero, A. I., \& Pujari, D. (2009). Customer Involvement in New Service Development: An Examination of Antecedents and Outcomes. Journal of Product Innovation Management, 26(5), 536-550. http://dx.doi.org/10.1111/j.1540-5885.2009.00679.x

Davenport, T., \& Pruzak, L. (2000). Working knowledge: How organizations manage what they know. The Journal of Technology Transfer, 26(4), 396-397. http://dx.doi.org/10.1145/347634.348775

Davenport, T., Harris, J., \& Kohli, A. (2001). How do they know their customers so well? MIT Sloan Management Review, 42(2), 63.

Day, G. S. (2000). Capabilities for forging customer relationships. Marketing Science Institute, (118).

Desouza, K., \& Awazu, Y. (2004). Gaining a competitive edge from your customers.

Etgar, M. (2007). A descriptive model of the consumer co-production process. Journal of the Academy of Marketing Science, 36(1), 97-108. http://dx.doi.org/10.1007/s11747-007-0061-1

García-Murillo, M., \& Annabi, H. (2002). Customer knowledge management. Journal of the Operational Research Society, 53(8), 875-884. http://dx.doi.org/10.1057/palgrave.jors.2601365

Gebert, H. et al. (2003). Knowledge-enabled customer relationship management: integrating customer relationship management and knowledge management concepts. Journal of Knowledge Management, 7(5), 107-123. http://dx.doi.org/10.1108/13673270310505421

Gibbert, M., Leibold, M., \& Probst, G. (2002). Five Styles of Customer Knowledge Management, and How Smart Companies Use Them To Create Value. European Management Journal, 20(5), 459-469. http://dx. doi.org/10.1016/S0263-2373(02)00101-9

Grissemann, U. S., \& Stokburger-Sauer, N. E. (2012). Customer co-creation of travel services: The role of company support and customer satisfaction with the co-creation performance. Tourism Management, 33(6), 1483-1492. http://dx.doi.org/10.1016/j.tourman.2012.02.002

Grönroos, C. (2011). A service perspective on business relationships: The value creation, interaction and marketing interface. Industrial Marketing Management, 40(2), 240-247. http://dx.doi.org/10.1016/j.ind marman.2010.06.036 
Hanvanich, S., Dröge, C., \& Calantone, R. (2003). Reconceptualizing the meaning and domain of marketing knowledge. Journal of Knowledge Management, 7(4), 124-135. http://dx.doi.org/10.1108/13673270 310492994

Hoyer, W. D. et al. (2010). Consumer Cocreation in New Product Development. Journal of Service Research, 13(3), 283-296. http://dx.doi.org/10.1177/1094670510375604

Kracht, J., \& Wang, Y. (2010). Examining the tourism distribution channel: Evolution and transformation. International Journal of Contemporary Hospitality Management, 22(5), 736-757. http://dx.doi.org/10. $1108 / 09596111011053837$

Lusch, R. F., Vargo, S. L., \& O’Brien, M. (2007). Competing through service: Insights from service-dominant logic. Journal of Retailing, 83(1), 5-18. http://dx.doi.org/10.1016/j.jretai.2006.10.002

McKeen, J., \& Smith, H. (2003). Making IT happen: Critical issues in IT management.

Payne, A. F., Storbacka, K., \& Frow, P. (2007). Managing the co-creation of value. Journal of the Academy of Marketing Science, 36(1), 83-96. http://dx.doi.org/10.1007/s11747-007-0070-0

Payne, A., Storbacka, K., \& Frow, P. (2009). Co-Creating Brands: Diagnosing and Designing the Relationship Experience. Journal of Business Research, 62(3), 379-389. http://dx.doi.org/10.1016/j.jbusres.2008.05.013

Reinartz, W., \& Kumar, V. (2002). The mismanagement of customer loyalty. Harvard business review, 80(7), $86-95$.

Rowley, J. (2002). Eight questions for customer knowledge management in e-business. Journal of Knowledge Management, 6(5), 500-511. http://dx.doi.org/10.1108/13673270210450441

Shaw, G., Bailey, A., \& Williams, A. (2011). Aspects of service-dominant logic and its implications for tourism management: Examples from the hotel industry. Tourism Management, 32(2), 207-214. http://dx.doi.org/10. 1016/j.tourman.2010.05.020

Smith, H. (2005). Developments in Practice XVIII-Customer Knowledge Management: Adding Value for Our Customers. Communications of the Association for Information Systems, 16, 744-755.

Vargo, S. L., Maglio, P. P., \& Akaka, M. A. (2008). On value and value co-creation: A service systems and service logic perspective. European Management Journal, 26(3), 145-152. http://dx.doi.org/10.1016/j. emj.2008.04.003

Zack, M. (2003). Rethinking the knowledge based organization. MIT Sloan Management Review.

Zanjani, M., Rouzbehani, R., \& Dabbagh, H. (2008). Proposing a conceptual model of customer knowledge management: A study of CKM tools in British dotcoms. International Journal of Human and Social Sciences, (136).

\section{Copyrights}

Copyright for this article is retained by the author(s), with first publication rights granted to the journal.

This is an open-access article distributed under the terms and conditions of the Creative Commons Attribution license (http://creativecommons.org/licenses/by/3.0/). 